\title{
Brazilian Scientific Mobility Program - Science without Borders* - Preliminary Results and Perspectives**
}

\author{
CONCEPTA MCMANUS ${ }^{1}$ and CARLOS A. NOBRE ${ }^{2}$
}

${ }^{1}$ Director of International Affairs, Capes, Full Professor, University of Brasilia, Asa Norte, 70040-020 Brasília, DF, Brazil ${ }^{2}$ Ex-president of Capes, Professor of Post-Graduate Programs, INPE, Jd. Granja, 12227-010 São José dos Campos, SP, Brazil

Manuscript received on November 29, 2016; accepted for publication on January 14, 2017

\begin{abstract}
The Brazilian Scientific Mobility Program - Science without Borders (SwB) - saw the concession of over 101 thousand scholarships for Brazilian STEM students and education professionals to attend universities worldwide. As the first phase of this program ends, it is time to take a first look at its impacts, mainly on the undergraduate student body ( $79 \%$ of total scholarships implemented). Benefits included a 6 -month language course (optional), a one year undergraduate course and optional 2 month internship in a university, government laboratory or technology company. Positive impacts have been seen on entrance into postgraduate programs ( $>20 \%$ of SwB students compared to $<5 \%$ of the overall student body of similar fields), as well as high representation of lower income families ( $>50 \%$ from families with less than 6 minimum wages per month). The impact of the program will need to be evaluated over the next years, but innovation on the part of the students is already apparent. Any new SwB program needs to take into account the lessons learned from this first experience and therefore recommendations are presented.
\end{abstract}

Key words: innovation, internationalization, scholarships, social impact, STEM areas.

\section{INTRODUCTION}

As the economy becomes more knowledgeintensive (Martin 2012), the need for academics to link their work more closely to economic needs becomes more evident. The State therefore has more specific requirements as to the production of universities with respect to increasing the scientific content of technologies (Suzigan and Albuquerque 2011).

Correspondence to: Concepta McManus

E-mail: concepta@unb.br

*Translated from the Portuguese "Ciência Sem Fronteiras"

** Contribution to the centenary of the Brazilian Academy of Sciences.
The Brazilian public university system has experienced extraordinary growth over the past 15 years, creating numerous new universities and campi throughout the country, substantially increasing the opportunities for better quality higher education. The same happened with postgraduate education (Masters and $\mathrm{PhD}$ ). Currently, there are over 4,300 postgraduate programs, and more than 250 thousand students, over 100 thousand of which are doctorate students. Brazil annually produces about 18 thousand PhDs and 55 thousand Masters. At this rate, Brazil will have an average of $2 \mathrm{PhDs}$ per thousand inhabitants in the coming years, far from developed countries with averages between 
5 and $20 \mathrm{PhDs}$ per thousand inhabitants (OECD 2015a). The expansion of the university system absorbed most new PhDs, and $75 \%$ of PhDs in the country are currently working in universities and government agencies (CGEE 2012), with a significantly lower number employed in companies and businesses (Santos et al. 2014), unlike the industrialized countries where innovative companies hire most of the PhDs (OECD 2015a).

For countries such as Brazil, where a gap can be identified between university output and scientific and technological needs (Barata 2014), the interactions between universities and firms are fundamental in terms of institutional building and require modernization to compete in today's world. According to Ortega and Bagnato (2015), activities conducted in a university environment are important as these are no longer institutions just for training human resources and course administration, but are now shapers of behavior and skills for the development of innovation. According to these authors, in countries such as Brazil, the practice of innovation through public universities is incipient and needs to be enhanced through the adoption of specific measures. Unfortunately, the available literature is too limited to be able to clarify how the universities of such countries practice innovation.

University-industry (U-I) cooperation generates innovation, learning, and mutual benefits (Closs and Ferreira 2012), and Universities are also a player or key partner for most of the 70 start-up technological parks/centers established in Brazil in the past two decades, where innovation is the main objective. Freire (2011) showed the importance of postgraduate training for Biotechnology companies in Brazil, and of the 11 cited biotechnology parks with incubated companies, 6 are in public universities. According to Carrer et al. (2010), in Brazil, around $85 \%$ of all incubated companies have strong bonds with universities or research institutes. There is still plenty of room for growth in U-I technology transfer as most U-I interaction is based on non-routine engineering, technical consultancy and human-resource training (Rapini 2007).

Nager et al. (2016) indicate that $20 \%$ of innovations are collaborations between multiple institutions, and half of these are public-private partnerships between private companies and universities or government research labs. Public research labs in the US were involved in 13 percent of innovations, and universities accounted for another 7 percent. The main indicators of immaturity in the Brazilian innovation system include a low proportional density of researchers in the country as stated above, a persistently unstable funding structure (Helene and Ribeiro 2011), imbalances between areas of knowledge, and the predominance of a cross-sectional pattern of research induction that tends to separate public and private sector priorities (Guimarães 2014). Of 40 countries surveyed, Brazil had the lowest percentage of STEM degrees in 2012 at 11\% (OECD 2015a), a very small number of international patents, with most of them by universities and not by innovative companies ( $\mathrm{Za}$ wislak and Dalmarco 2011).

On the other side is the number of staff trained for research - 68,507 lecturers in the post-graduate system - which has produced important new knowledge in recent years, meaning that Brazil is the $13^{\text {th }}$ generator in the number of scientific papers worldwide (Almeida et al. 2013). Nevertheless, the impact of these papers, as measured by citations in the scientific literature, is less than the world average, with most Brazilian research being cited by Brazilians (Ponomariov and Toivanen 2014). Brazil is a user of technology-oriented knowledge rather than producer, which leads to the question of how to make national science more visible and show higher impact. In all diagnoses the recurring theme of the urgency of internationalization of Brazilian universities, increased cooperation with advanced research centers around the world and more joint production of new knowledge with research- 
ers from other countries becomes evident. Furtado et al. (2015) shows that the homogeneous development of research institutions and environments throughout the country is negatively impacted by restricted mobility.

The internationalization of Brazilian universities is required to make higher education responsive to the requirements and challenges of a globalized society. This international mobility refers to both faculty and students. The internationalization of these universities has the potential to transform the lives of international students and has a supporting role in the growth of science and knowledge through intense academic exchange as well as to aids in building social and economic capabilities. The impact of this process persists over time and so investments made need to be consolidated through well-structured public and university policies.

This also requires that a much greater number of foreign students come to study in Brazil. In particular, for post-graduate education, less than $2 \%$ of graduate students in the country are foreigners, a figure much smaller than the post-graduate education system of developed nations where it ranges from an average of $14 \%$ at the Masters' level to $24 \%$ at the doctorate level in OECD nations, with Switzerland having 52\% foreign students at the doctorate level (OECD 2015b). Most of the approximately 4000 foreign graduate students in Brazil come from Spanish or Portuguese-speaking countries in Latin America and Africa, with Columbian students making up 35\% of doctorate and $39 \%$ of masters students, followed by Peru with $21 \%$ overall (Figure 1). Almost all of these students are within the PEC-PG (Programa de Estudantes - Convênio de Pós-Graduação) run by CAPES (doctorate), CNPq (Masters) and the Ministry of Foreign Affairs.

Today, no Ph.D. programs in Brazil are fully carried out in English (although students may present their theses and dissertations and individual disciplines may be taught in this language), unlike those in other non-English speaking countries such as the Netherlands, Japan, or Norway, to cite just a few. Therefore, science mobility is necessary in both directions according to the paradigm of 'brain circulation' rather than the less desirable 'brain drain' or 'brain gain'. Graduate programs - especially a large fraction of the more than $400 \mathrm{Ph} . \mathrm{D}$. programs ranked as of international excellence by CAPESneed to adopt English as their working language to become truly internationalized, which is seen as a gargantuan challenge due to the deeply seated cultural attachment to Portuguese by graduate students, due in part to inadequate knowledge of English (Foster 2014).

In light of the relatively low international mobility of Brazilian students, the Presidential Decree 7642/2011 instituted the Brazilian Scientific Mobility Program, also called Science without Borders (SwB). The program was created as a response to deficiencies noted within the Brazilian superior education system as well as to follow a directive presented by National Postgraduate Plan (NPP). Its goal consisted in contributing to the internationalization of Brazilian universities, improving Brazilian researcher mobility, increasing the qualification within the STEM areas (science, technology, engineering and mathematics), and still, consequently, changing the innovation paradigm in the Brazil. The SwB included, from 2015 (Resolução Normativa CNPq 017/2015), the professional masters program, to attend another directive present in the NPP which was the approximation between productive sector and academia, as well as improve the possibility of innovation outside the university environment, trying to follow the principles of the Triple Helix Model (Leydesdorff and Etzkowitz 1998, Ranga and Etzkowitz 2010). Data from 2011 to 2015 show that the main areas of full doctorates abroad paid by Capes were in the social science areas (Figure 2).

This program was a five year "social experiment", sending 92,880 Brazilian students 


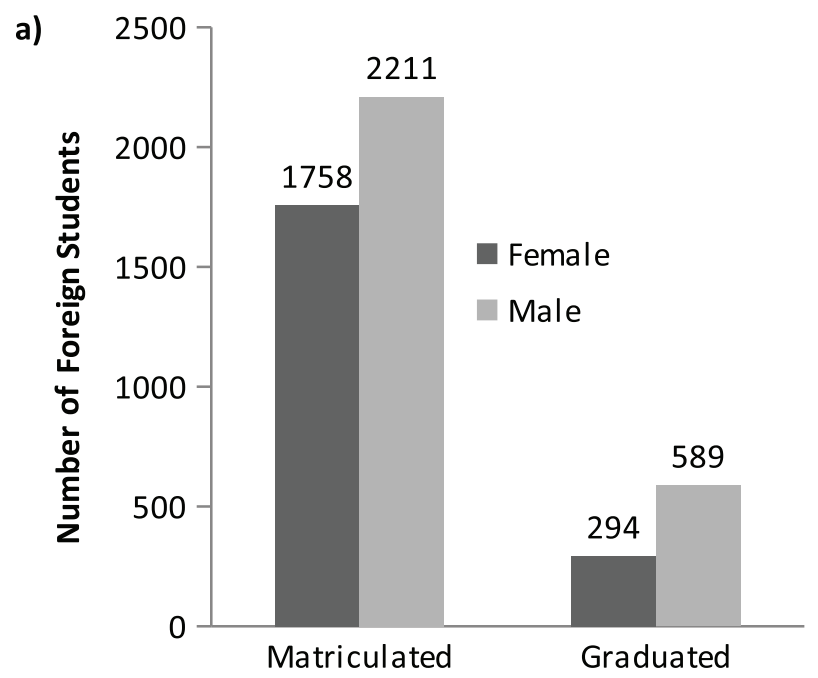

b) Doctorate Students

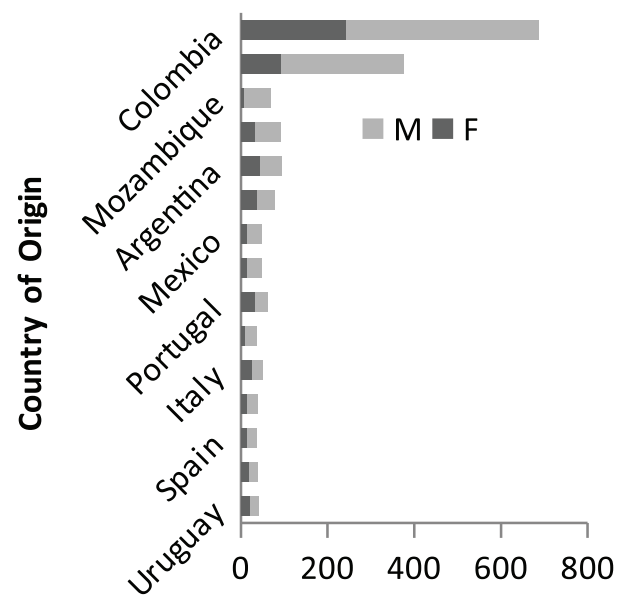

Number of Students c) Masters Students

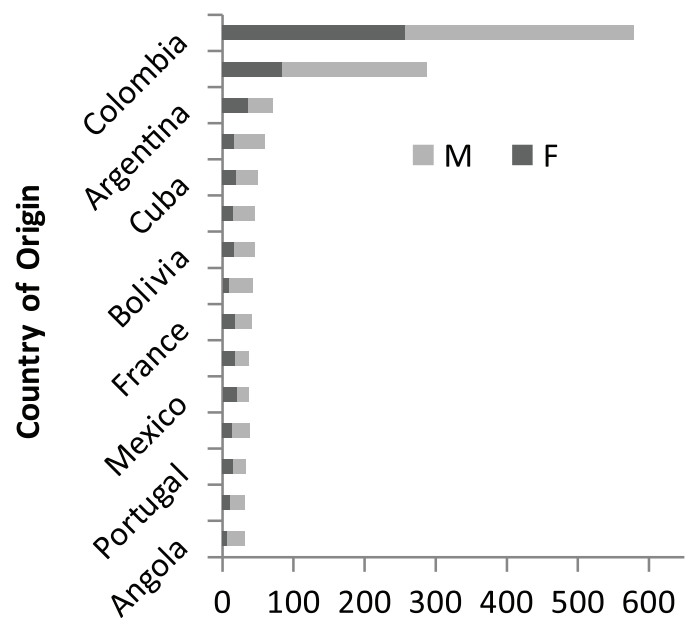

Number of Students

Figure 1 - Foreign students matriculated as well as degrees granted in 2014 (a) by country of origin for doctorate (b) and masters (c) in Brazilian Postgraduate Education. Source: Sucupira Platform/CAPES.

and higher education professionals to study abroad for periods varying from one (undergraduate, sandwich doctorate, visiting scholar and post doctorate research) to four years (full doctorate). The program also included 6 months training in a foreign language before beginning the university studies, when necessary, as well as a two month internship afterwards for undergraduate students. It should be noted that the last general calls for scholarships within the program were in 2014 effectively ending the program.

\section{RESULTS}

Most of the scholarships offered within the SwB program were completed by 2016 . The program was under the guidance of the Home Secretary's office (directly linked to the president), with CAPES (Brazilian Agency for Postgraduate Education) 


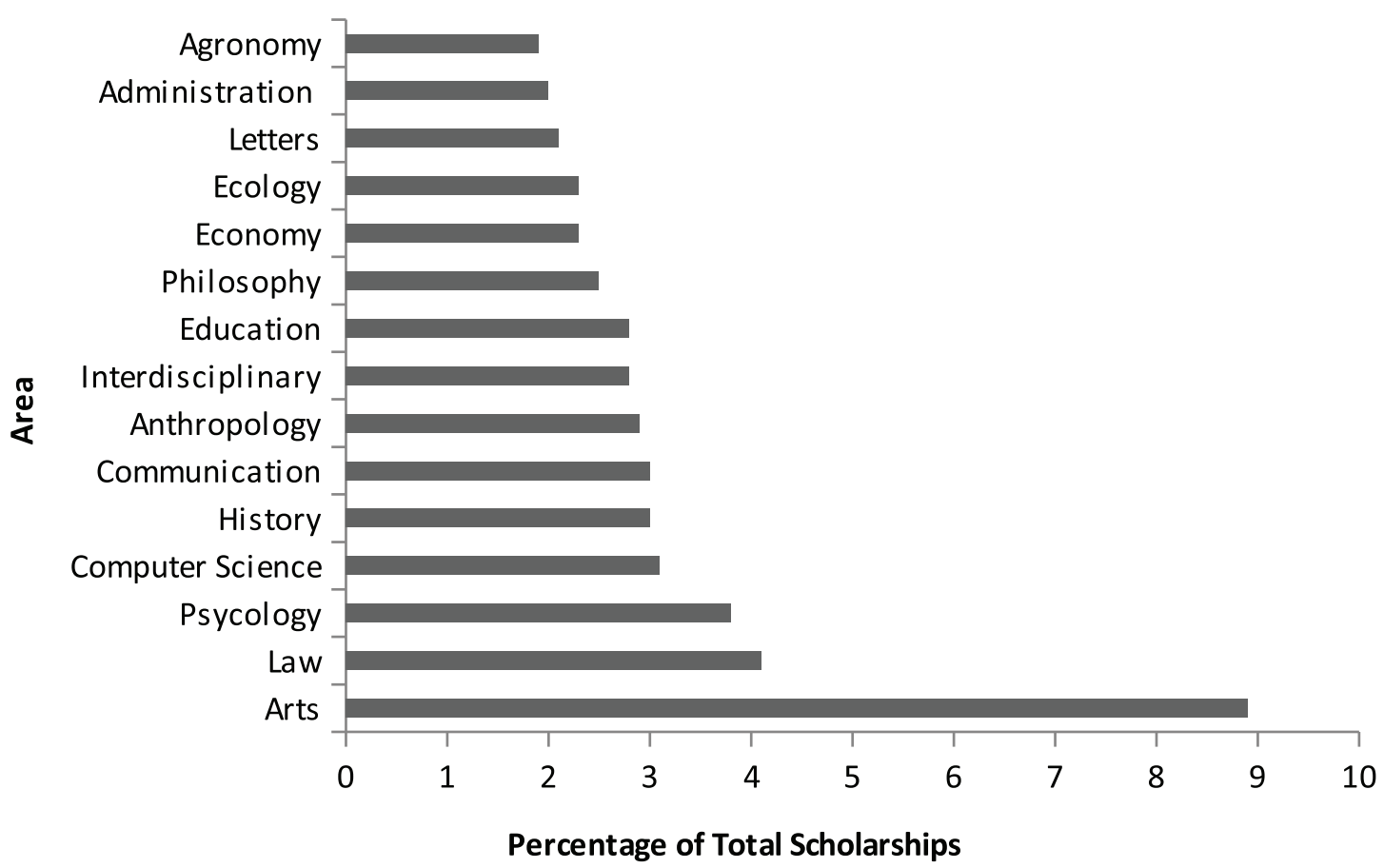

Figure 2 - Areas of knowledge of Brazilian full doctorate scholarship holders (2011-2015).

and $\mathrm{CNPq}$ (National Science Foundation) being the two federal agencies responsible for program implementation, with approximately $70 \%$ of the scholarships being implemented by CAPES. These are now beginning to evaluate the results of the program. The program should be evaluated compared to the originally pre-defined objectives. While it is still too early to estimate the impact of the program on technology issues and innovation in Brazil or even its contribution to the internationalization of Brazilian universities, the initial results are encouraging. The last graduate students returned from abroad at the end of 2016 and there is need for at least five years after their return to evaluate their entry into the labor market or postgraduate school. The analysis here will concentrate on undergraduate students who made up $79 \%$ of the students sent abroad. Much data can be found on the SwB control panel (http://www. cienciasemfronteiras.gov.br/web/csf/painel-decontrole), but here we look more closely at some particular aspects of the program results.
Goal 1: Increase the presence of researchers and students at all levels in foreign institutions of excellence;

A total of 73,353 undergraduate students were sent for an academic year to 2,912 universities, including 182 of the top 200 universities in the world in "Shanghai Ranking - Academic Ranking of World Universities"1, from 54 countries (Figure 3 ), as well as 87 of the top 88 universities in the US. Of these students, more than $40 \%$ had optional summer internships at university, government and industrial laboratories, further expanding their involvements with innovative environments. Internships took place in companies such as Boeing, AbbVie, Amgen, Merck, Cargill, Dupont, and in government laboratories such as NIH and NASA, among many others.

Brazil increased the number of students and researchers abroad from a pre-SwB average of around 5 thousand per year to more than 40

\footnotetext{
${ }^{1}$ High correlations were seen for this question between Shanghai, Times Higher Education and QS rankings
} 


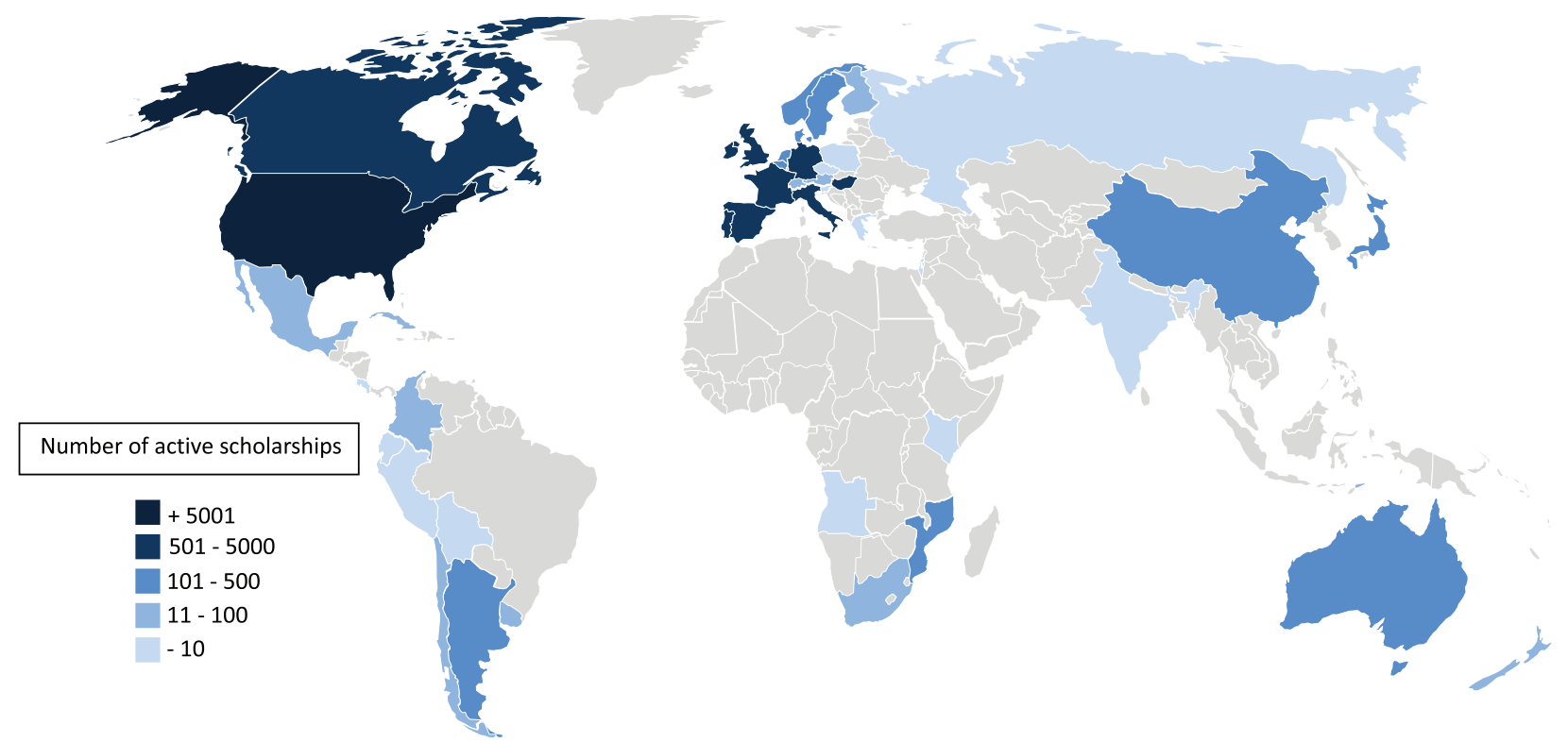

Figure 3 - Active SwB scholarships in 2015.

thousand in 2015 (Figure 4), at the height of SwB. The scholarships also included those for 4,649 post doctorate fellows, 3,351 doctorates, 775 visiting researchers, 558 masters' students, 9,680 sandwich doctorates and 504 young researchers attracted to Brazil.

The original goal was to offer 101,000 scholarships and this was achieved in 2015. Nevertheless 7,839 students opted not to accept the undergraduate scholarship, of which $6 \%$ were admitted into postgraduate courses in Brazil.

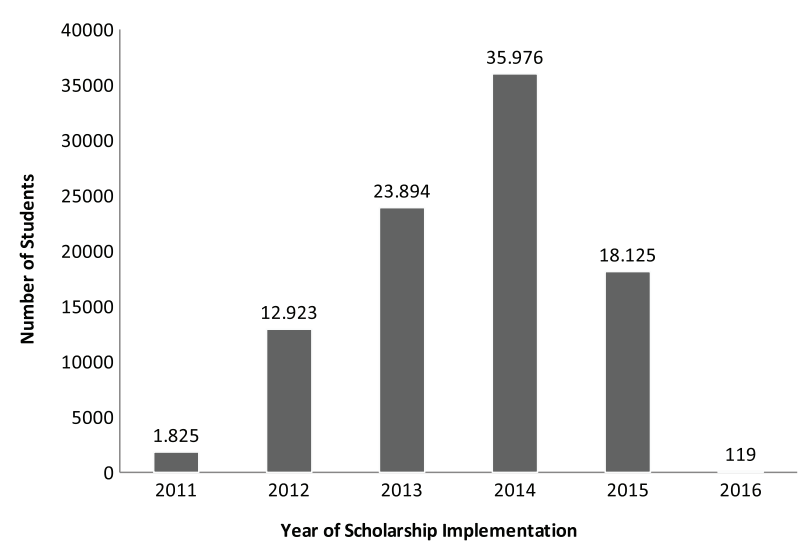

Figure 4 - Number of SwB scholarships implemented per year (Capes and $\mathrm{CNPq}$ ).
The number of scholarships rose steadily from $2011(1,825)$ to $2014(35,976)$, when the program reached its peak. The areas of the implemented scholarships were STEM (Figure 5), with a concentration in the areas of engineering, biological and health sciences.

Most scholarships were implemented in the USA, followed by the UK, Canada, France and Australia (Figure 6). This is in line with the major mobility scholarships implemented by other countries (Kim and Locke 2010, Chang and Kono 2014). The University of Toronto received the highest number of students $(1,218)$ followed by the University of California (all campi) $(1,196)$ and California State University (949). Most students originated in São Paulo State $(19,232)$, followed by Minas Gerais $(15,925)$ and Rio de Janeiro $(8,126)$.

The number of scholarships varied per the region of Brazil where the student resided (Figure 7), with a greater proportion in the Northeastern (NE) region for undergraduate scholarships followed by the Southern (S) and Southeastern (SE) regions. This may reflect the investments made in the NE in university education in recent decades as well as the result of recent efforts to promote increased 


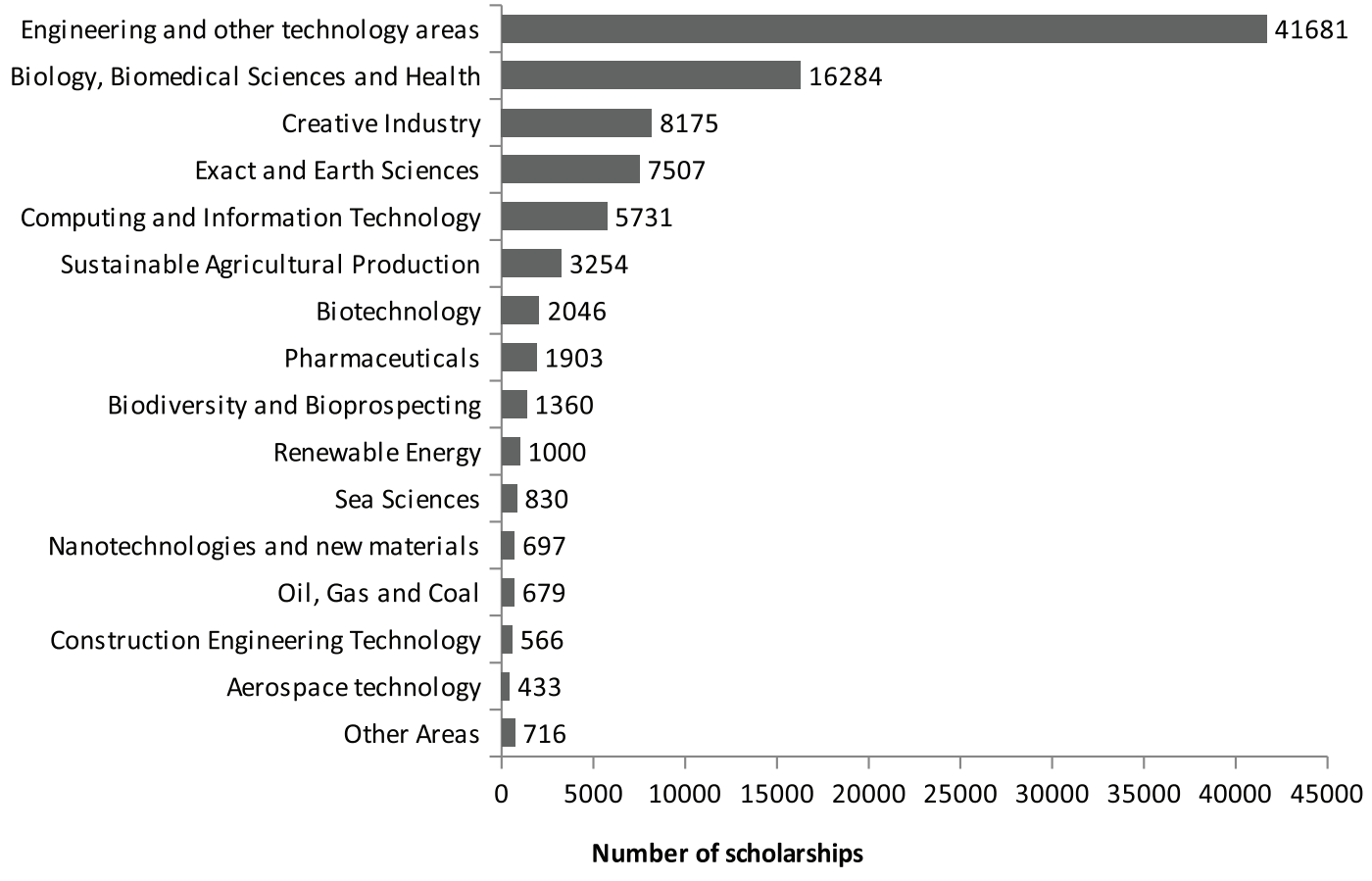

Figure 5 - Number of undergraduate SwB students for each of the Program's priority areas (Capes and CNPq).

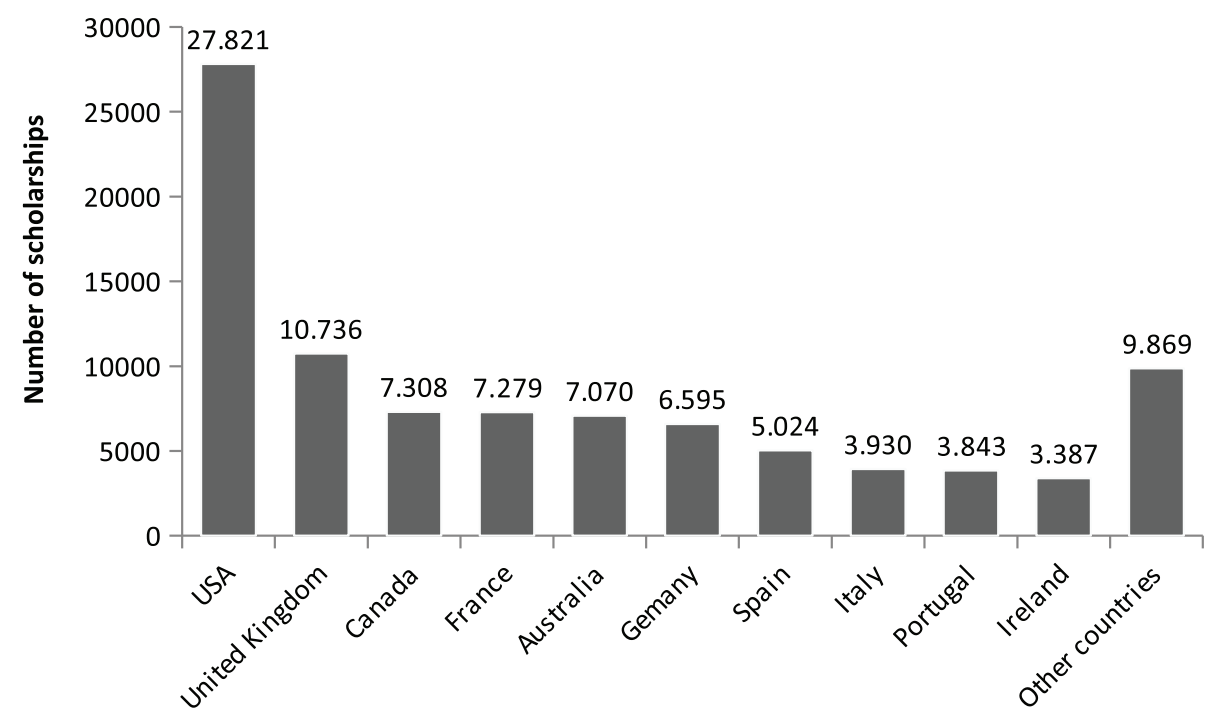

Figure 6 - Destination countries of undergraduate SwB students (Capes and CNPq).

balance among higher education institutions between Brazilian regions (Capes, 2010), while the postgraduate (B) distribution reflects the overall level of development of the postgraduate system in the $\mathrm{S}$ and $\mathrm{SE}$ regions.

This assessment shows encouraging preliminary results on social inclusion. Fifty-two percent of sandwich-type undergraduate students come from families with incomes up to six minimum wages and $75 \%$ up to 10 minimum wages (Figure 8). Considering all undergraduate students, $25.5 \%$ of those replying to a CAPES questionnaire (62 thousand replies) declared themselves of AfroBrazilian descendency (Figure 9), close to the level of 
a)
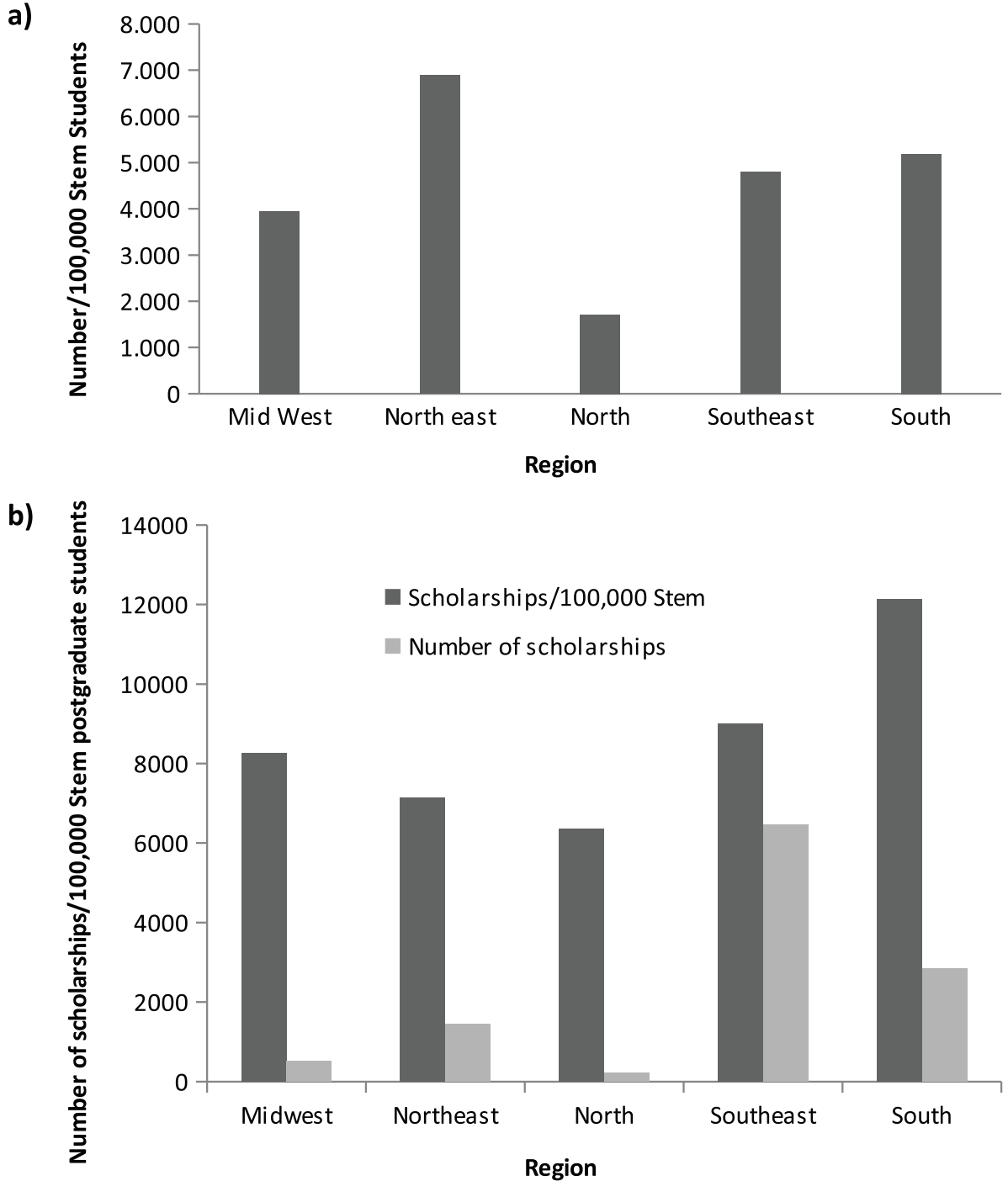

Figure 7 - Number of SwB scholarship holders per 100.000 students in Stem/SwB areas for different regions of Brazil for a) undergraduate and $\mathbf{b}$ ) sandwich doctorate scholarships (from the Capes postgraduate database).

the participation of this ethnic group in the Brazilian university system (23\%). The same questionnaire found that 695 students indicated having some deficiency, mostly visual (48\%), and $42 \%$ were already in the work place, mostly with part time or sporadic work. $10 \%$ indicated that they worked full time in Brazil as well as studying. As to their high school education, $31 \%$ came from public schools and another $20 \%$ from private schools where they had a scholarship. These are positive results that were not anticipated. These young people had a unique opportunity to spend a year at a top university, become fluent in another language and gain an international experience that will certainly open professional and personal paths that they would be unlikely to attain otherwise. It is worthy of note that, of the 5,408 SwB students registered in the Ministry of Labour (2013/2014), 54\% were in the engineering area, followed by $12 \%$ in computing and $9 \%$ in biology.

$44 \%$ of the undergraduate students on SwB were female, somewhat less than the overall number 


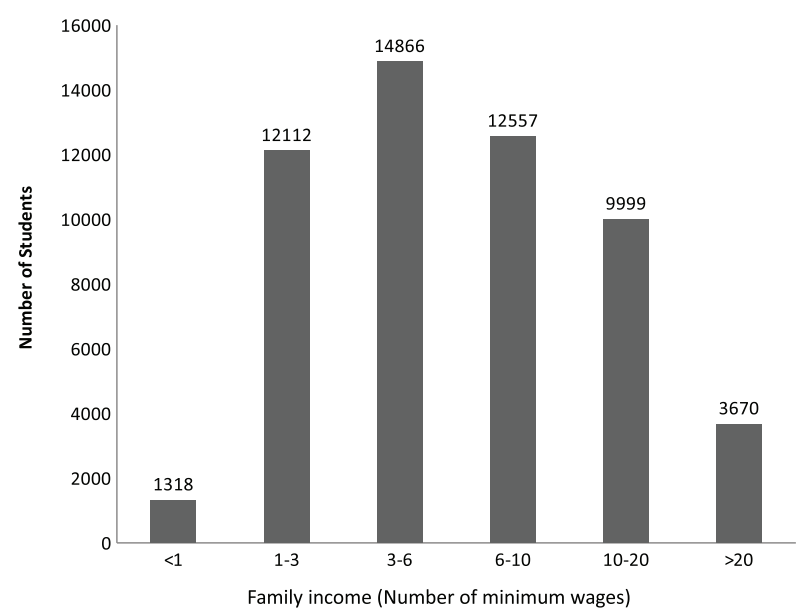

Figure 8 - Number (and \%) of undergraduate SwB student by family income as measured by number of minimum wages.

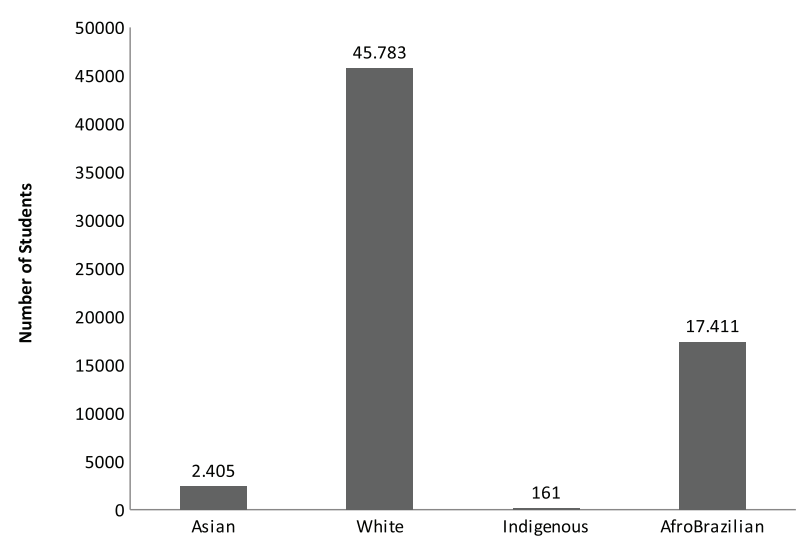

Figure 9 - Number of undergraduate SwB students by ethnic origin.

enrolled in undergraduate courses in universities in Brazil with $55 \%$ of enrollments and $60 \%$ of those graduating. Nevertheless, when we look at STEM areas there is tendency for this percentage to fall (47.4\% female and $52.5 \%$ male) (Data from Education Census 2013, Brazil). In postgraduate education, approximately $54 \%$ of the students sent on sandwich doctorates were female, in line with the $52 \%$ doing postgraduate work in STEM areas (Capes postgraduate data base - Sucupira 20132015).

Goal 2: Invest in training of highly qualified personnel in the necessary skills and abilities to the advancement of a knowledge based society
The longer term impacts of $S w B$ can be assessed by analyzing those participants who have completed undergraduate courses in Brazil after returning from abroad. The present study is exploratory, as not all students have returned from abroad and many that have returned have not yet completed their undergraduate education. A mandatory criterion for participation in $S w B$ was a score of least 600 points in the ENEM (national end of high school exam). Of the 2011/2012 cohorts (analysis sample of undergraduate 12,517 students, the only ones for which full data are available), more than 20\% subsequently enrolled in Master's and $\mathrm{PhD}$ courses, a far greater number than the $<5 \%$ of graduates in the same priority areas of SwB and $>600$ points in the ENEM (Figure 10). The monitoring of graduates should continue to assess the impact of this program both for the internationalization of Brazilian universities and for the emergence of more young innovators and entrepreneurs within the domestic industry.

Goal 3: Expand the innovative knowledge of personal in technological industries;

The innovation of the program's students is already evident from their actions back in Brazil. The creation of a SwB Network shows this clearly with 15 core groups in home universities created by the students themselves (www.redeCsF.org), with plans to create an international core. These actions include the creation of a FabLab, a digital fabrication laboratory that facilitates prototyping ideas, encouraging innovation and invention and the opening of a German office in Minas Gerais State, led by a former scholar who promoted meetings between German researchers and local farmers to discuss the use of alternative energy methods.

\section{SHARING KNOWLEDGE AND ENTREPRENEURSHIP}

Back in Brazil, alumni use the knowledge acquired abroad to improve the academic development of those who remained in the country. Here we can cite examples such as those students who held 


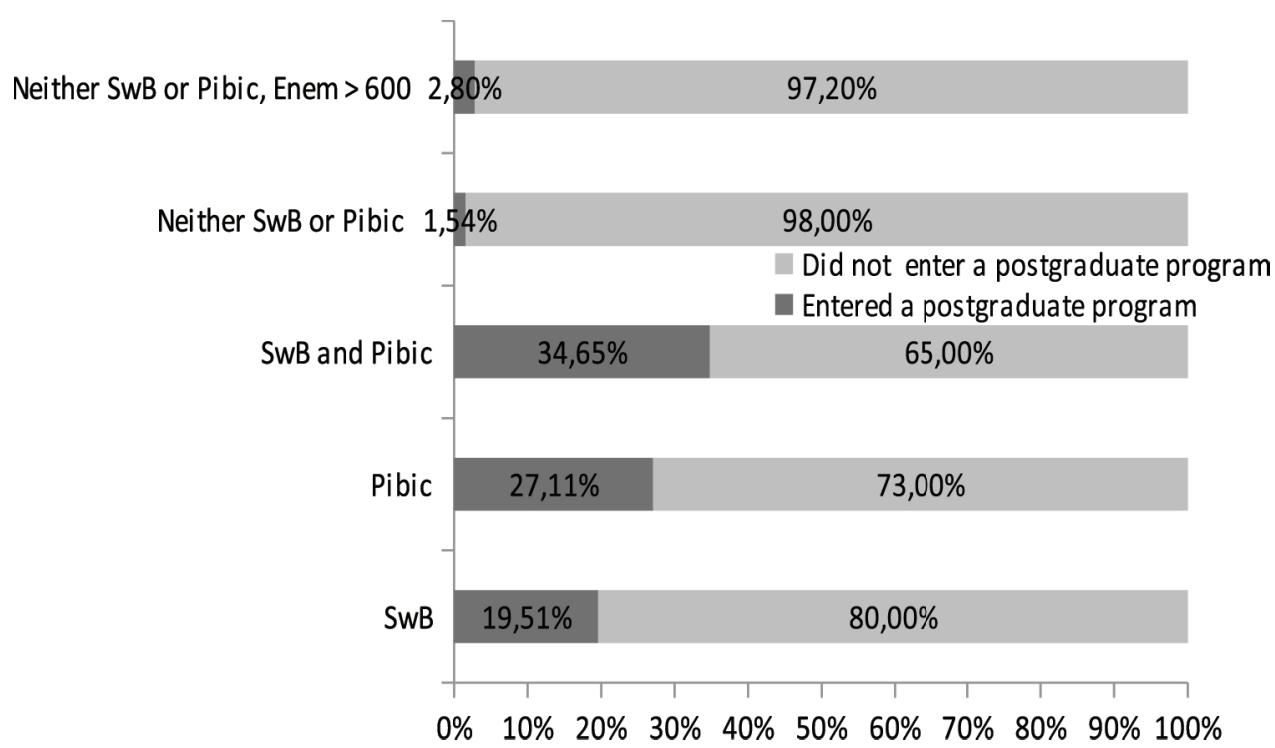

Figure 10 - Percentage of 2011/2012 cohort SwB undergraduate students that entered postgraduate system. (Pibic is a one-year undergraduate research program aiming to prepare students for postgraduate studies, Enem is a national end of high school exam. To apply for the SwB program after 2012 students had to achieve a score of $>600$ in the Enem).

short courses at their universities of origin on the knowledge obtained abroad, as well as the creation of the Language Network at the Federal University of Viçosa including English, French, German and Italian classes, aimed at teaching foreign languages to high school students. A book written by an exalumni "The man who saved New York from lack of water" seeks to help in the discussion of the global water crisis, bringing twelve stories of sustainable solutions to environmental problems, mainly on the issue of water. Alumni are also establishing partnerships with NGOs to obtain financial support for undergraduate projects.

Polyteck magazine, created by an exscholarship holder, is an education and science communication project, seeks to complement the training of Brazilian students and an application that promotes female empowerment in business through digital platforms was financed by NASA and was a finalist in competitions organized by the $\mathrm{UN}$ and Google. Another ex-student fabricated a 3D printer, used in the manufacture of prototypes, and created his own business while another founded
The Pilot School for Chemical Engineering, based on his experience abroad. The initiative has already impacted more than 300 graduate students. These are just a few of the results that have been identified, but a fuller investigation will need to be carried out once the full impacts of the program can be measured.

Goal 4: Promote international insertion of Brazilian institutions by opening similar opportunities for foreign scientists and students; and Goal 5: Attracting young scientific talents and highly qualified researchers to work in Brazil.

With the implementation of the program, Brazil appeared on the radar of the countries that are the largest producers of world knowledge. Thus, Capes signed 184 agreements with countries from the United States to China and Sweden to Australia. On the down side, without a constant sustainable program, countries and universities that received a large number of students during SwB have seen these numbers dwindle considerably which can also affect the diplomatic and academic relationships between these institutions. 
Preliminary results show that $33 \%$ of the first group of young researchers from abroad, attracted by $\mathrm{SwB}$, were contracted within the Brazilian universities. 775 renowned scientists have been working, publishing and innovating with Brazilian researchers, including Nobel Prize Winner, Swiss scientist Kurt Wüthrich. All regions received senior researchers from abroad aiming at distribution of knowledge throughout the country as regions such as the Midwest, Northeast and North are frequently cited as being less well developed. The impact of this should be seen in the next few years with an increase in the quality and impact of research published in Brazil, as well as an increase in innovation and technology in the STEM areas. Nevertheless, the original goal of attracting 2,000 visiting scientists and 2,000 young scientists was not met (Table I), and it highlights some of the difficulties of implementing the concept of "brain circulation", a more meaningful way of cooperation in comparison with "brain drain" or "brain gain".

The program received some criticisms from the participants in a survey carried out by the Brazilian Senate (http://www25.senado.leg.br/web/ atividade/materias/-/materia/119979). Frequently selection of the University for study and student placement was carried out by international agencies. Where in the senate study, $43 \%$ rated the former as regular to very bad, and $15 \%$ considered the university where they were placed in these same categories, which obviously needs to be reviewed for future programs. Some students experienced difficulty in having the class credits obtained abroad recognized back in their original university in Brazil, while others were not able to study in their university of choice. Nevertheless, the overall evaluation showed $97 \%$ of the students evaluate the experience as good or great. Some similar results were seen by Filippini et al. (2016) with SwB students in Italy.

Another comment received was the low number of students in the top 25 universities worldwide. If we look at admission numbers, universities such as MIT (Massachusetts Institute of Technology) or Harvard have intakes of approximately 1.100 to 1.600 students per year, while larger universities such as Oxford or Cambridge take in approximately 3.200 students of all nationalities. The number of SwB undergraduate students sent abroad represents approximately $50 \%$ of all UK university admissions in a single year. The intake was also not in the first year of the course, which is the usual case, but in the middle, thereby requiring adaptation by receiving universities which normally function on a yearly basis, different from the semester and individual discipline choice system practiced by Brazilian universities. Many of the aforementioned universities were thereby unwilling/unable to change their admission systems to accommodate the SwB candidates. Another point important to

TABLE I

Original goals and number implemented by type of scholarship.

\begin{tabular}{lrrrrrr}
\hline \multicolumn{1}{c}{ Scholarship } & Goal $(\mathrm{G})$ & Granted $(\mathrm{Gd})$ & Implemented (I) & $\mathrm{Gd} / \mathrm{G}$ & $\mathrm{I} / \mathrm{G}$ & $\mathrm{I} / \mathrm{Gd}$ \\
\hline Undergraduate & 64,000 & 78,980 & 73,353 & 1.23 & 1.15 & 0.93 \\
Sandwich Doctorate & 15,000 & 11,684 & 9,685 & 0.78 & 0.65 & 0.83 \\
Full Doctorate & 4,500 & 3,365 & 3,353 & 0.75 & 0.75 & 1.00 \\
Young Talents & 2,000 & 946 & 504 & 0.47 & 0.25 & 0.53 \\
Post-doctorate & 6,440 & 6,243 & 4,652 & 0.97 & 0.72 & 0.75 \\
Special Visiting Researcher & 2,000 & 2,025 & 775 & 1.01 & 0.39 & 0.38 \\
Technological development and Innovation ${ }^{1}$ & 7,060 & 599 & 558 & 0.08 & 0.08 & 0.93 \\
\hline Total & 101,000 & 103,842 & 92,880 & 1.02 & 0.92 & 0.9 \\
\hline
\end{tabular}

${ }^{1}$ This scholarship was implemented as Professional Masters. Data compiled in August 2016, totals may change when final numbers are computed. 
note is that while a university may not be cited as "top" in the overall ranking, it may be better ranked for specific areas of knowledge, so care must be taken when making broad criticisms of this sort.

Brazilian students generally did well academically, opening collaboration opportunities and expanding international visibility of Brazil in the educational, technical and scientific fields. Students of SwB received awards at several levels, including NASA Lunabotics Mining Competition and a suborbital flight award with the second Brazilian to have an experience in space being a SwB student.

As to the future, any new internationalization program should have annual planning and set sustainable budgets with intensive negotiations of fees and tuitions with international partners. The program should be based within the scholarship agencies and not directly under government control and should actively include universities and other government agencies in the formulation of the program stimulating the creation sustainable partnerships/networks between Brazilian and Foreign HEIs. The experience gained in completion of this first phase of the program recommends several improvements: 1) promote a greater participation of graduate students and researchers in post-doctoral stage, since the benefit for researchers in international centers of excellence is immeasurable; 2) send undergraduate students to a smaller number of pre-defined universities, but all cutting edge, and mainly involve the Brazilian university of origin of students in co-tutoring and internship monitoring abroad, expanding partnerships with target universities as well as preparing these young students for studying abroad (all bi-lateral agreements should be in place before the implementation of a new program); 3 ) distribute students more evenly over several countries and promote the exchange of students to increase the number of foreigners in Brazilian universities; 4) set specific budgets for the program that do not encroach on the basic funding of the science, technology and innovation system (noting that one of the relevant criticisms to SwB was the use of funding from the most important public research fund - National Fund for Scientific and Technological Development/FNDCT- for the payment of scholarships and fees for undergraduate students in SwB); 5) significantly increase the attraction of foreign researchers to the Brazilian university system; 6) exclude foreign language training abroad from the program, given the online system "Idioms without Frontiers" (http://isf.mec. gov.br/) is available for free to the candidates; 7) include non-STEM areas that are also important for the sustainable development of the country, as social and human improvement depend not just of hard sciences, but also other fields closely linked to creativity and subjectivity; 8) guarantee the recognition of study credits and degrees obtained abroad back in Brazil. Capes data show that there was about $47 \%$ of full credit recognition with problems varying from the student not requesting recognition to the university refusing, or overlap with credits already coursed by the student; 9) improved negotiations with the private sector in Brazil for funding scholarships in specific areas, especially targeted to the production sector (in the original proposal private companies were programmed to invest in approximately 26 thousand of the scholarships, but by 2015 this investment was about 20 thousand); and 10) develop mechanisms to consolidate the knowledge obtained in these internationalization programs back in Brazil.

The total cost of the SwB over four years is estimated to be (Brazilian reais) over R $\$ 13$ billion or an average of R $\$ 131$ thousand per undergraduate student compared with an annual cost of US\$ 10 thousand for students in public universities in Brazil (OECD 2015b). This takes into account an increase in the dollar exchange rate from R\$1.6/US\$1 when the program was conceptualized in 2011 to $\mathrm{R} \$ 4.1 /$ US\$1 during 2015, when the highest number of 
students were abroad. This increase had a strong negative impact on the Brazilian postgraduate system, as funding authorities had to use their resources to maintain these students abroad. There is also a need for changes within HEIs for the adoption of practices related to Internationalization at Home as most of Brazilian student and faculty (Elsevier, 2015) may not have the opportunity to study abroad. Higher education internationalization programs following the guidelines laid down above can reduce significantly such costs.

SwB was an innovative experience and leaves us many lessons. The internationalization of Brazilian universities requires the international mobility of faculty and the student body seen in the program, but higher education institutions in Brazil need to be more actively involved in this process for it to be more sustainable and so that long-term partnerships can be cultivated with foreign partners.

\section{ACKNOWLEDGMENTS}

Thanks are due to Coordenação de Aperfeiçoamento de Pessoal de Nível Superior (CAPES) and Conselho Nacional de Desenvolvimento Científico e Tecnológico (CNPq) public servants who compiled the data. These include Adi Balbinot Junior, Cyntia Sandes Oliveira, Helena Carneiro de Albuquerque, Fernando Augusto Pimenta Kreismann, Amanda Pereira Ferraz, Geraldo Sorte, Geraldo Nunes Sobrinho, Sérgio da Costa Cortes, Luis Filipe de Miranda Grochocki, Andréa Carvalho Vieira, Vanessa Fernandes de Araújo Vargas, Marilene Maria Augusto Vieira, Miguel Araújo da Cunha, Letícia Valéria Porfírio, Ana Elisa Rover Oliveira, Fabrício Nascimento Carrijo, Denise Neddermeyer, Jorge Guimarães, Patrício Pereira Marinho, Ângela Sugamosto Westphal, Jussara Pereira Prado, Junio Flores Lopes, Suellen Maria Santos de Oliveira, Clarissa Soares, Amanda Olímpio de Menezes, Priscilla de Medeiros de Abreu, Pedro Henrique Oliveira Miranda and all
DRI/Capes staff among many others. Thanks are also due to the Directorate of Technology and Information/Capes as well as the Brazilian Foreign Office (Itamaraty) and Embassies worldwide.

The opinions expressed here are solely those of the authors and do not represent those of government or funding agencies.

\section{REFERENCES}

ALMEIDA E, CHAVES E AND GUIMARÃES JA. 2013. Brazil's growing production of scientific articles: how are we doing with review articles and other qualitative indicators? Scientometrics 97(2): 287-315.

BARATA RB. 2014. Academicism versus innovation: challenges for the Brazilian science and technology system. Cad Saúde Púb 30(8): 1602-1603.

CAPES. 2010. Plano Nacional de Pós-Graduação - PNPG 2011-2020. https://www.capes.gov.br/images/stories/ download/Livros-PNPG-Volume-I-Mont.pdf.

CARRER CC, PLONSKI GA, CARRER CRO AND OLIVEIRA CEL. 2010. Innovation and entrepreneurship in scientific research. Rev Bras Zoot 39(Supl spe): 7-25.

CGEE 2012. Mestres 2012: Estudos da demografia da base técnico-científica brasileira - Brasília, DF: Centro de Gestão e Estudos Estratégicos, 2012, 427 p.

CHANG L AND KONO Y. 2014. International Student Mobility Trends 2014: The Upward Momentum of STEM Fields. W Ed News Rev 27(2). Retrieved from http://wenr. wes.org/2014/03/international-student-mobility-trends2014-the-upward-momentum-of-stem-fields.

CLOSS LQ AND FERREIRA GC. 2012. University-industry technology transfer in the Brazilian context: a review of scientific studies published from 2005 to 2009. Gest Prod 19: 419-432.

ELSEVIER. 2015. World of Research 2015: Revealing patterns and archetypes in scientific research. Elsevier, 348 p.

FILIPPINI G, KNIAZ R AND ATTIANI C 2016. Italian Universities and Academic Cooperation with Brazil: lessons learnt from Science without Borders. In: FAUBAI Congress, Fortaleza, Brazil. Retrieved from: http://www. faubai.org.br/conf/2016/submissions/modules/request. php? module $=$ oc_program\&action=summary.php\&id $=21$.

FOSTER M. 2014. Student destination choices in higher education: Exploring attitudes of Brazilian students to study in the United Kingdom. J Res Int Ed 13: 149-162.

FREIRE CT. 2011. Brazil Biotech map 2011. Retrieved from http://www.cebrap.org.br/v2/files/upload/biblioteca virtual/item_419/22_03_12_17Brazil\%20Biotec\%20 Map\%202011.pdf.

FURTADO CA, DAVIS CA Jr, GONÇALVES MA AND DE ALMEIDA JM. 2015. A Spatiotemporal Analysis of 
Brazilian Science from the Perspective of Researchers' Career Trajectories. PLoS ONE 10(10): e0141528.

GUIMARÃES R. 2014. Light and shadow in the Brazilian graduate studies system in health. Cad Saúde Púb 30(8): 1591-1608.

HELENE AF AND RIBEIRO PD. 2011. Brazilian scientific production, financial support, established investigators and doctoral graduates. Scientometrics 89: 677-686.

KIM T AND LOCKE W. 2010. Transnational academic mobility and the academic profession. Centre for Higher Education Research and Information, The Open University, London, p. 27-34.

LEYDESDORFF L AND ETZKOWITZ H. 1998. The triple helix as a model for innovation studies (conference report). Sci Pub Pol 25(3): 195-203.

MARTIN BR. 2012. Are universities and university research under threat? Towards an evolutionary model of university speciation Camb J Econ 36: 543-565.

NAGER A, HART DM, EZELL S AND ATKINSON RD. 2016. The Demographics of Innovation in the United States, 86 p. https://itif.org/publications/2016/02/24/demographics-innovation-united-states.

OECD. 2015a. OECD Science, Technology and Industry Scoreboard 2015. Innovation for Growth and Society, $259 \mathrm{p}$.

OECD. 2015b. Education at a glance 2015: OECD Indicators, $510 \mathrm{p}$.
ORTEGA LM AND BAGNATO VS. 2015. The practice of innovation at Brazilian public university: the case of the University of São Paulo. Braz J Sci Technol 2: 6.

PONOMARIOV B AND TOIVANEN H. 2014. Knowledge flows and bases in emerging economy innovation systems: Brazilian research 2005-2009. Research Policy 43: 588596.

RANGA M AND ETZKOWITZ H. 2013. Triple Helix Systems: An Analytical Framework for Innovation Policy and Practice in the Knowledge Society. Ind High Ed 27(4): 237-262. Special Issue "Innovation policy as a concept for developing economies: renewed perspectives on the Triple Helix system". http://triplehelix.stanford.edu/images/ Triple_Helix_Systems.pdf.

RAPINI MS. 2007. Interação universidade-empresa no Brasil: evidências do Diretório dos Grupos de Pesquisa do CNPq. Estud Econ (SP) 37: 211-233.

SANTOS DFL, BASSO LFC, KIMURA H AND KAYO EK. 2014. Innovation efforts and performances of Brazilian firms J Bus Res 67: 527-535.

SUZIGAN W AND ALBUQUERQUE EM. 2011. The underestimated role of universities for the Brazilian system of innovation. Rev Econ Pol 31: 3-30.

ZAWISLAK PA AND DALMARCO G. 2011. The Silent Run: New Issues and Outcomes for University-Industry Relations in Brazil. J Tech Manag Innov 6: 66-82. 